\title{
Optimization of Process Parameters for Foam Mat Dried Papaya Powder
}

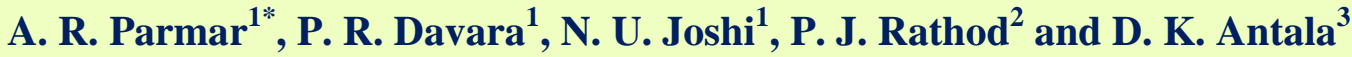 \\ ${ }^{1}$ Department of Processing and Food Engineering, ${ }^{2}$ Department of Biochemistry, ${ }^{3}$ Department \\ of Renewable Energy Engineering, College of Agricultural Engineering and Technology, \\ Junagadh Agricultural University, Junagadh, Gujarat, India \\ *Corresponding author
}

\section{A B S T R A C T}

\section{Keywords \\ Papaya, Foam mat, Drying, Carica papaya L., Foaming properties \\ Article Info \\ Accepted: \\ 07 October 2020 \\ Available Online: \\ 10 November 2020}

Foam mat drying of papaya pulp was undertaken by foaming of papaya pulp using foaming agent and foaming stabilizer in thin layer drying. Whey protein isolate was used as foaming agent and methyl cellulose was used as foaming stabilizer. The effect of three foaming parameters viz., foaming agent $(2.5,5.0,7.5,10.0$ and $12.5 \%$, w/w), foaming stabilizer $(0.2,0.4,0.6,0.8$ and $1 \%$, w/w) and whipping time $(5,10,15,20$ and $25 \mathrm{~min})$ were optimized by keeping criteria as maximum foam expansion, maximum foam stability and minimum foam density of papaya pulp using response surface methodology. The optimum foaming conditions were found to be $6.55 \%$ foaming agent, $0.57 \%$ foaming stabilizer and 13.09 min whipping time. The experimental values of foam expansion of $148.63 \%$, foam stability of $74.16 \%$ and foam density of $0.38 \mathrm{~g} / \mathrm{cc}$ were found at this optimized process parameters.

\section{Introduction}

Papaya (Carica papaya L.) is one of the important tropical and subtropical fruit in the world, originated in Mexico as a cross between two species of the genus Carica. India is one of the leading producers of papaya, contributing around $43 \%$ in the world production in 2016 (Anon., 2018). Gujarat stands at second position in the country and the total Production of papaya in Gujarat was about 12.07 lakh MT with a cultivated area of 0.19 lakh hectares during the year 2018-19 (Anon., 2019). In Gujarat, the Honey Dew, Washington, Pusa Dwarf and Taiwan are the major cultivars grown. Papaya is a wonderful source of antioxidants such as vitamin $\mathrm{C}$, carotenes and flavonoids; vitamin $\mathrm{B}$, pantothenic acid, folate; minerals, like potassium, magnesium and iron and fiber. Papaya can be made into jam, jelly, nectar, dried into slabs, canned in the form of slice and the fruit powder. The total postharvest loss of papaya worked out to $25.49 \%$ (Gajanana et al., 2010).

Foam mat drying is a simple and time efficient process used for heat sensitive products. It converts a semi-solid or a liquid into stable foam by incorporating an ample 
amount of air by using a foaming agent and stabilizing the emulsion by adding a stabilizer (Hardy and Jideani, 2017). It is an economical alternative to drum, spray and freeze-drying for the production of food powders (Kadam et al., 2010a).

A high-quality food powder can be obtained by the proper selection of foaming method, foaming agents, foam stabilizers, time taken for foaming, suitable drying method and temperature.

The dehydrated papaya by-products can be used for the preparation of a range of food product formulations such as ready to eat fruited cereals, snacks, ice cream flavours, nectar, instant soup cubes, bakery products, as a starter for the preparation of instant foods, pastes, etc., thus new processed food products from papaya are highly desirable (Kandasamy et al., 2012a).

Papaya, a tropical fruit has economic importance because of its potential nutritive and medicinal value. Papaya has a relative short postharvest shelf life. Preparation of good quality papaya powder by drying is one of the ways to add value to the product with longer shelf life. Foam-mat proffers the benefits of air drying, cheapness, and accessibility.

Foam mat drying yields powders with better reconstitution properties and superior quality compared to that produced by drum and spray drying (Morgan et al., 1961; Chandak and Chivate, 1974). The foam mat dried products are highly stable against deteriorative microbial, chemical and biochemical reactions (Rajkumar and Kailappan, 2006).

Looking to the above facts, the present research work was undertaken to optimize foaming and stabilizing process parameters for foam mat drying of ripe papaya pulp.

\section{Materials and Methods}

\section{Selection of Raw material}

The Honey Dew has become one of the most popular varieties for commercial plantations in Gujarat. Honey Dew variety has a less seeds and good taste and flavours. It is also known as Madhu Bindu because of high percentage of fruit sugar (Kumar and Abraham, 1943). In aspect of this, Honey Dew variety of papaya was selected for the present investigation. The ripened fruits were brought from local market of Junagadh, Gujarat, India. Whey protein isolate (WPI) as foaming agent and methyl cellulose (MC) as stabilizer were used within the limits fixed in the Prevention of Food Adulteration Act 1955 of the Government of India and based on preliminary foaming conducted (Rajkumar et al., 2007).

\section{Experimental design and treatment details}

The Response Surface Methodology (RSM) was used for designing of the experiment (Myers, 1976; Khuri and Cornell, 1987; Montgomery, 2001). After cutting papaya into small pieces, pulp was prepared with the help of mixture. The ripe papaya pulp (100g) sample was taken into the plastic cylindrical vessel for foaming. Based on preliminary experiments, an amount of $100 \mathrm{ml}$ water was added along with pre-determined quantity of foaming agents i.e. sample to water ratio of 1:1 (w/w) for formation of foam. Pulp was converted into foam from ripe papaya for more expansion, high stability and low density with the use of foaming agent and foaming stabilizer.

The independence variables such as concentration of whey protein isolate and the concentration of methyl cellulose were kept between $2.5-12.5 \%(\mathrm{w} / \mathrm{w})$ and $0.1-0.5 \%$ $(\mathrm{w} / \mathrm{w})$ respectively, and whipping time was 
kept 5-25 min. The coded and uncoded variable according to different combination of foaming agent, foaming stabilizer and whipping time was shown in Table 1.

\section{Foaming Properties}

\section{Foam Expansion}

Foam expansion was calculated from the volume of ripe papaya pulp before and after whipping using following formula reported by Durian (1995).

Foam Expansion $(\%)={ }^{\left[\frac{\mathrm{V}_{1}-\mathrm{V}_{\infty}}{\mathrm{V}_{\infty}}\right] \times} 100$

Where,

$\mathrm{V}_{0}=$ Initial volume of foam, $\mathrm{cm}^{3}$

$\mathrm{V}_{1}=$ Final volume of foam, $\mathrm{cm}^{3}$

\section{Foam Stability}

Foam stability of ripe papaya pulp was recorded by taking of foamed pulp in a transparent graduated beaker and kept for $3 \mathrm{~h}$. For foam stability, the reduction in foam volume was measured for every $30 \mathrm{~min}$. The foam, after $1 \mathrm{~h}$ was considered as mechanically and thermally stable foams for entire drying period (Kundra and Ratti, 2006). Foam stability was determined by using following formula:

Foam stability $(\%)=\left[\frac{\mathrm{V}_{a}}{\bar{V}_{1}}\right] \times 100$

Where,

$\mathrm{V}_{0}=$ Volume of foam at $180 \mathrm{~min}, \mathrm{~cm}^{3}$

$\mathrm{V}_{1}=$ Initial volume of foam including the liquid volume without foaming, $\mathrm{cm}^{3}$

\section{Foam Density}

The density of foamed ripe papaya pulp was analyzed in terms of mass by volume $(\mathrm{g} / \mathrm{cc})$ by Falade et al., (2003).
Foam density $(\mathrm{g} / \mathrm{cc})=\rho_{\mathrm{p}} \times^{\left[\frac{\mathrm{V}_{0}}{\mathrm{v}_{1}}\right] \times 100}$

Where,

$\rho_{\mathrm{p}}=$ density of pulp, $\mathrm{g} / \mathrm{cc}$

$\mathrm{V}_{0}=$ Initial volume of foam, $\mathrm{cm}^{3}$

$\mathrm{V}_{1}=$ Final volume of foam, $\mathrm{cm}^{3}$

\section{Data analysis}

A three-factor five-level Central Composite Rotatable Design (CCRD) with quadratic model was employed (1) to study the combined effect of three independent variables, viz., foaming agent $\left(\mathrm{X}_{1}\right)$, foaming stabilizer $\left(\mathrm{X}_{2}\right)$ and whipping time $\left(\mathrm{X}_{3}\right)$ on different response variables, (2) to create models between the variables, and (3) to determine the effect of these variables to optimize the selected response variables. A total of 20 combinations were carried out in random order according to a CCRD configuration for the three chosen variables. The response function (Y) was related to the coded variables by a second degree polynomial equation as given below:

$$
\mathrm{Y}=\mathrm{b}_{0}+\mathrm{b}_{1} \mathrm{X}_{1}+\mathrm{b}_{2} \mathrm{X}_{2}+\mathrm{b}_{3} \mathrm{X}_{3}+\mathrm{b}_{11} \mathrm{X}_{1}^{2}+\mathrm{b}_{22} \mathrm{X}_{2}^{2}+\mathrm{b}_{33} \mathrm{X}_{3}
$$$$
{ }^{2}+b_{12} X_{1} X_{2}+b_{13} X_{1} X_{3}+b_{23} X_{2} X_{3}
$$

Where,

$b_{0}$ is the constant, $b_{i}$ the linear coefficient, $b_{i i}$ the quadratic coefficient and $b_{i j}$ the interactive coefficient, $X_{i}$ and $X_{j}$ are the levels of the independent variable.

The obtained data were subjected to analyze for graphical representation, analysis of variance (ANOVA) and multiple regression using the software package Design Expert version 10.0.8 (Anderson and Whitcomb, 2005). The effect and regression coefficients of individual linear, quadratic and interaction terms were determined from the ANOVA tables. 


\section{Optimization and validation of model}

The Design Expert version 10.0.8 software was used for optimization of process variables. The optimum values of the selected variables were analyzed by the response surface contour plots and also by solving the regression equation. To check the validity and adequacy of the predicted models, the average experimental value of different response variables was used. The optimum condition to obtain the best quality foamed pulp was considered when the foam expansion and foam stability were as high as possible, whereas foam density was as low as possible

\section{Results and Discussion}

\section{Foaming characteristics of foamed papaya pulp}

The treatment wise values of different foaming characteristics of foamed papaya pup are presented in the Table 1. The experimental values of foam expansion, foam stability and foam density were found in the range of $102 \%$ to $155 \%, 40.56 \%$ to $79.67 \%$ and $0.36 \mathrm{~g} / \mathrm{cc}$ to $0.48 \mathrm{~g} / \mathrm{cc}$, respectively depending upon the experimental conditions.

From the Table 1, it can be observed that the maximum foam expansion was found as $155 \%$ for the treatment no. 16 having a combination of foaming agent, foaming stabilizer and whipping time at $7.5 \%, 0.6 \%$ and $15 \mathrm{~min}$, respectively. While the minimum foam expansion was observed in the treatment no. $14(102 \%)$ at foaming agent of $7.5 \%$, foaming stabilizer of 0.6 and whipping time of $25 \mathrm{~min}$. The highest value of foam stability was observed as $79.67 \%$ for the treatment no. 19 holding the combination of foaming agent, foaming stabilizer and whipping time at $7.5 \%$, $0.6 \%$ and $15 \mathrm{~min}$, respectively. The lowest value of foam stability was obtained for the treatment No. $11(40.56 \%)$ for which the value of foaming agent, foaming stabilizer and whipping time stands at $7.5 \%, 0.2 \%$ and 15 min, respectively. The maximum foam density was recorded as $0.48 \mathrm{~g} / \mathrm{cc}$ for the treatment no. 14 at a combination of foaming agent $(7.5 \%)$, foaming stabilizer $(0.6 \%)$ and whipping time $(25 \mathrm{~min})$. While minimum foam density was recorded as $0.36 \mathrm{~g} / \mathrm{cc}$ for the treatment no. 16 at combination of foaming agent $(7.5 \%)$, foaming stabilizer $(0.6 \%)$ and whipping time (15 $\mathrm{min})$.

\section{Response surface analysis}

The response surface curves for the individual response parameters were developed through Design Expert software. Each response surface curve explains the effect of two variables on response parameters while keeping the third variable fixed at middle level. The Analysis of Variance (ANOVA) and regression analysis of the different response parameters is given in the Table 2 .

\section{Foam Expansion}

\section{Effect of foaming agent and foaming stabilizer on foam expansion}

The response surface curve for the variation in the foam expansion of papaya as a function of foaming agent $\left(\mathrm{X}_{1}\right)$ and foaming stabilizer $\left(\mathrm{X}_{2}\right)$ is shown in Fig. 1(a). It shows the interactive effect of foaming agent and foaming stabilizer on the foam expansion of papaya pulp, keeping the whipping time $\left(\mathrm{X}_{3}\right)$ at middle level, i.e. $15 \mathrm{~min}$. The increase in foam expansion was observed as the foaming agent increased up to $5.66 \%$ and foaming stabilizer up to $0.55 \%$ as indicated in the Fig. 3. The foam expansion at this combination was proposed to be increased up to $153.039 \%$. The foam expansion was decreased with further increase in foaming agent and foaming stabilizer beyond this combination. This might be due to saturation point of foaming 
agent at this point of interaction. The solubility of foaming agent at higher concentration was decreased causing the reduction or no further rise in the foam expansion. Similar findings were also reported by Kandasamy et al., (2012a) during his experiment on foaming of papaya pulp.

\section{Effect of foaming agent and whipping time on foam expansion}

The effect of foaming agent $\left(\mathrm{X}_{1}\right)$ and whipping time $\left(\mathrm{X}_{3}\right)$ on foam expansion of papaya pulp, keeping foaming stabilizer $\left(\mathrm{X}_{2}\right)$ at middle level, i.e. $0.6 \%$ is graphically represented in the Fig. 1(b). The foam expansion was increased with an increase in foaming agent and whipping time up to $5.44 \%$ and $13.47 \mathrm{~min}$, respectively. At this combination of foaming agent and whipping time, the foam expansion of pulp was expected to be increased up to $153.04 \%$. The foam expansion of pulp was found to be decreased with further increase in foaming agent and whipping time. The excessive whipping (overbeating) caused foam to collapse which was the main reason for decreasing the foam expansion at higher level of whipping time.

\section{Effect of foaming stabilizer and whipping time on foam expansion}

The effect of foaming stabilizer $\left(\mathrm{X}_{2}\right)$ and whipping time $\left(\mathrm{X}_{3}\right)$ on foam expansion of papaya pulp by keeping foaming agent $\left(\mathrm{X}_{1}\right)$ constant at middle level i.e. $7.5 \%$ is shown in Fig. 1(c). The foam expansion was found to be increased as the foam stabilizer and whipping time was increased up to $0.55 \%$ and $13.69 \mathrm{~min}$, respectively. For this combination of foaming stabilizer and whipping time, the foam expansion of pulp was proposed to be increased up to $150.722 \%$. Beyond this combination, the foam expansion was observed to be decreased.

\section{Regression analysis of foam expansion}

The regression analysis and ANOVA results for the foam expansion of papaya pulp are shown in the Table 2. The negative linear effect of foaming agent and whipping time was observed on foam expansion at significance of $p<0.001$ and of $p<0.01$, respectively. The similar linear effect was also induced by the foam stabilizer but statistically it was not significant.

The quadratic effect of all the individual parameters, i.e., foaming agent, foaming stabilizer and whipping time, was negative on foam expansion at $0.1 \%$ level of significance. The interaction effect between foaming agent and foaming stabilizer was found positive at significance of $\mathrm{p}<0.05$. However, the interaction between foaming stabilizer and whipping time and interaction between foaming agent and whipping time were found to be positive but statistically it was not significant. The derived model giving the empirical relationship between the foam expansion and the test variables in coded units was obtained as under:

Foam expansion $=150.43-7.44 \mathrm{X}_{1}-1.19 \mathrm{X}_{2}$ - 4.06 $X_{3}+3.87 X_{1} X_{2}+1.37 X_{1} X_{3}+3.25$ $\mathrm{X}_{2} \mathrm{X}_{3}-6.03 \mathrm{X}_{1}^{2}-9.47 \mathrm{X}_{2}^{2}-10.47 \mathrm{X}_{3}^{2}$

Where, $X_{1}, X_{2}$ and $X_{3}$ are the coded factors of foaming agent, foaming stabilizer and whipping time, respectively.

The calculated F-value, $\mathrm{R}^{2}$, Adj- $\mathrm{R}^{2}$, Pred. $\mathrm{R}^{2}$ and Adeq. Precision values for foam expansion 33.68, 0.9681, 0.9393, 0.800, 16.31, respectively, indicating the adequacy, good fit and high significance of the model. The small value of coefficient of variation (3.34\%) for foam expansion explained that the experimental results were precise and reliable (Table 2). 


\section{Foam stability}

Effect of foaming agent and foaming stabilizer on foam stability

The effect of foaming agent $\left(\mathrm{X}_{1}\right)$ and foaming stabilizer $\left(\mathrm{X}_{2}\right)$ on foam stability of papaya pulp, keeping whipping time $\left(\mathrm{X}_{3}\right)$ at middle level, i.e. $15 \mathrm{~min}$ is graphically presented in the Fig. 2(a). It could be observed from the contour graph, that the foam stability was increased with an increase in foaming agent and foaming stabilizer up to $7.5 \%$ and $0.6 \%$, respectively. At this interaction of foaming agent and whipping time, the foam stability of pulp was expected to be increased up to $76.26 \%$. The foam stability of pulp was found to be decreased with further increase in foaming agent and foaming stabilizer.

Table.1 Experimental values of different foaming properties of papaya pulp

\begin{tabular}{|c|c|c|c|c|c|c|}
\hline \multirow[t]{2}{*}{ Treatment } & \multicolumn{3}{|c|}{ Uncoded variables } & \multicolumn{3}{|c|}{ Responses } \\
\hline & $\begin{array}{l}\text { Foaming } \\
\text { agent }(\%)\end{array}$ & $\begin{array}{c}\text { Foaming } \\
\text { stabilizer }(\%)\end{array}$ & $\begin{array}{l}\text { Whipping } \\
\text { time (min) }\end{array}$ & $\begin{array}{c}\text { Foam } \\
\text { expansion } \\
(\%)\end{array}$ & $\begin{array}{c}\text { Foam } \\
\text { stability } \\
(\%)\end{array}$ & $\begin{array}{c}\text { Foam } \\
\text { density } \\
(\mathrm{g} / \mathrm{cc})\end{array}$ \\
\hline 1 & 5 & 0.4 & 10 & 150 & 60 & 0.38 \\
\hline 2 & 10 & 0.4 & 10 & 115 & 65 & 0.46 \\
\hline 3 & 5 & 0.8 & 10 & 125 & 57.14 & 0.43 \\
\hline 4 & 10 & 0.8 & 10 & 120 & 55.34 & 0.44 \\
\hline 5 & 5 & 0.4 & 20 & 125 & 56.5 & 0.43 \\
\hline 6 & 10 & 0.4 & 20 & 110 & 54.67 & 0.47 \\
\hline 7 & 5 & 0.8 & 20 & 127.5 & 54.89 & 0.42 \\
\hline 8 & 10 & 0.8 & 20 & 113.5 & 55.59 & 0.47 \\
\hline 9 & 2.5 & 0.6 & 15 & 140 & 51.67 & 0.4 \\
\hline 10 & 12.5 & 0.6 & 15 & 115 & 63.33 & 0.46 \\
\hline 11 & 7.5 & 0.2 & 15 & 115 & 40.56 & 0.46 \\
\hline 12 & 7.5 & 1 & 15 & 112.5 & 45.71 & 0.47 \\
\hline 13 & 7.5 & 0.6 & 5 & 117.5 & 57.33 & 0.45 \\
\hline 14 & 7.5 & 0.6 & 25 & 102 & 49.29 & 0.48 \\
\hline 15 & 7.5 & 0.6 & 15 & 152.5 & 72.38 & 0.37 \\
\hline 16 & 7.5 & 0.6 & 15 & 155 & 75.45 & 0.36 \\
\hline 17 & 7.5 & 0.6 & 15 & 150 & 74.29 & 0.38 \\
\hline 18 & 7.5 & 0.6 & 15 & 147.5 & 77.04 & 0.39 \\
\hline 19 & 7.5 & 0.6 & 15 & 150 & 79.67 & 0.38 \\
\hline 20 & 7.5 & 0.6 & 15 & 150 & 79.29 & 0.38 \\
\hline
\end{tabular}


Table.2 Analysis of variance (ANOVA) and regression coefficients for response surface quadratic model of different foaming properties of papaya pulp

\begin{tabular}{|c|c|c|c|}
\hline Source & $\begin{array}{c}\text { Foam expansion } \\
(\%)\end{array}$ & $\begin{array}{c}\text { Foam stability } \\
(\%)\end{array}$ & $\begin{array}{c}\text { Foam density } \\
(\mathrm{g} / \mathrm{cc})\end{array}$ \\
\hline Intercept & $150.43 * * *$ & $76.32 * * *$ & $0.37 * * *$ \\
\hline \multicolumn{4}{|c|}{ Linear terms } \\
\hline $\mathbf{A}\left(\mathbf{X}_{1}\right)$ & $-7.44 * * *$ & 1.59 & $0.019 * * *$ \\
\hline $\mathbf{B}\left(\mathbf{X}_{2}\right)$ & -1.19 & -0.18 & 0.0025 \\
\hline $\mathbf{C}\left(\mathbf{X}_{3}\right)$ & $-4.06 * *$ & $-1.99 *$ & $0.009^{*}$ \\
\hline \multicolumn{4}{|c|}{ Interaction terms } \\
\hline $\mathbf{A B}\left(X_{1} X_{2}\right)$ & $3.87 *$ & -0.53 & -0.008 \\
\hline $\operatorname{AC}\left(X_{1} X_{3}\right)$ & 1.37 & -0.54 & 0.00 \\
\hline $\mathbf{B C}\left(\mathbf{X}_{2} \mathbf{X}_{3}\right)$ & 3.25 & 1.48 & -0.005 \\
\hline \multicolumn{4}{|c|}{ Quadratic terms } \\
\hline $\mathrm{A}^{2}\left(\mathrm{X}_{1}{ }^{2}\right)$ & $-6.03 * * *$ & $-4.73 * * *$ & $0.014 * * *$ \\
\hline $\mathbf{B}^{2}\left(\mathbf{X}_{2}^{2}\right)$ & $-9.47 * * *$ & $-8.32 * * *$ & $0.022 * * *$ \\
\hline$C^{2}\left(X_{3}^{2}\right)$ & $-10.47 * * *$ & $-5.78 * * *$ & $0.022 * * *$ \\
\hline \multicolumn{4}{|c|}{ Indicators for model fitting } \\
\hline $\mathbf{R}^{2}$ & 0.9681 & 0.9548 & 0.9472 \\
\hline $\operatorname{Adj}-R^{2}$ & 0.9393 & 0.9141 & 0.8996 \\
\hline Pred-R ${ }^{2}$ & 0.8001 & 0.7398 & 0.7165 \\
\hline Adeq Precision & 16.31 & 14.04 & 11.85 \\
\hline F-value & 33.68 & 23.48 & 19.92 \\
\hline Lack of fit & NS & NS & NS \\
\hline C.V. \% & 3.34 & 5.53 & 3.01 \\
\hline
\end{tabular}

$\mathrm{A}$ or $\mathrm{X}_{1}=$ Foaming agent, $\mathrm{B}$ or $\mathrm{X}_{2}=$ Foaming stabilizer, $\mathrm{C}$ or $\mathrm{X}_{3}=$ Whipping time, $* * *$ Significant at $\mathrm{p}<0.001$, $* *$ Significant at $\mathrm{p}<0.01, *$ Significant at $\mathrm{p}<0.05, \mathrm{NS}=$ Non-significant

Fig.1 Effect of foaming agent, foaming stabilizer and whipping time on foam expansion of papaya pulp

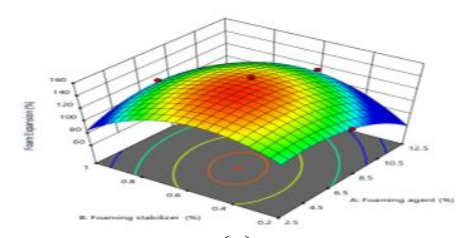

(a)
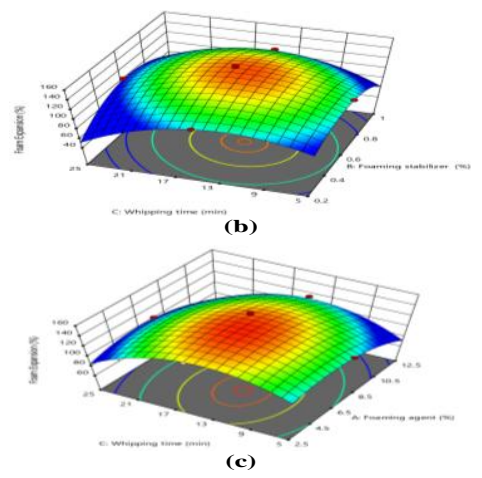
Fig.2 Effect of foaming agent, foaming stabilizer and whipping time on foam stability of papaya pulp
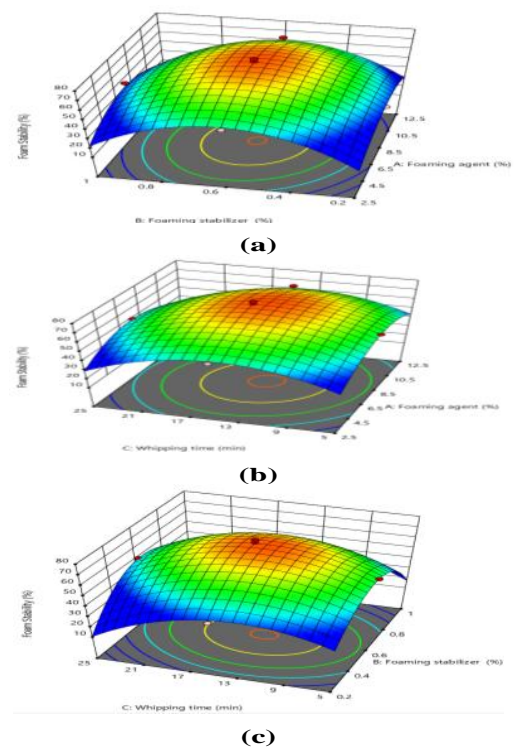

Fig.3 Effect of foaming agent, foaming stabilizer and whipping time on foam density of papaya pulp

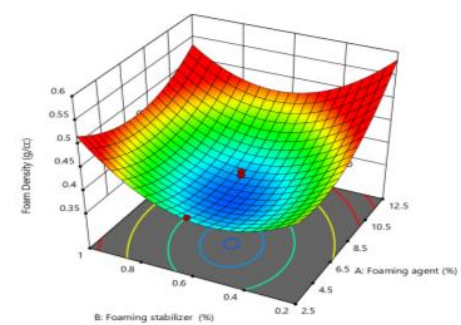

(a)

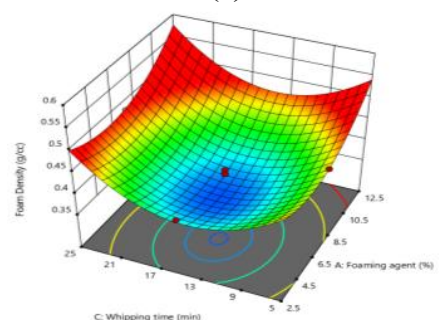

(b)

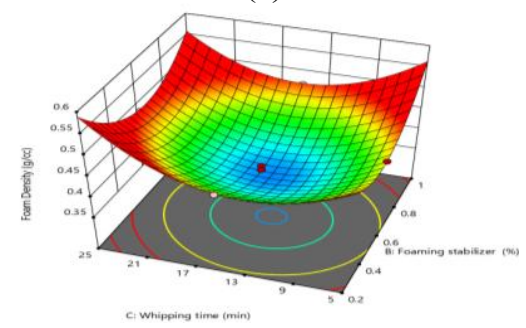

(c) 


\section{Effect of foaming agent and whipping time on foam stability}

The response surface curve for the variation in the foam stability of papaya as a function of foaming agent $\left(\mathrm{X}_{1}\right)$ and whipping time $\left(\mathrm{X}_{3}\right)$ is shown in Fig. 2(b). It shows the interactive effect of foaming agent and whipping time on the foam stability of papaya pulp, keeping the foam stabilizer $\left(\mathrm{X}_{2}\right)$ at middle level, i.e. $0.6 \%$. The increase in foam stability was observed as the foaming agent and whipping time increased up to $7.77 \%$ and $13.54 \mathrm{~min}$, respectively. At this combination of foaming agent and whipping time, the foam stability of pulp was expected to be increased up to $76.47 \%$. The foam stability of pulp was found to be further decreased with increase in foaming agent and whipping time beyond this interaction.

\section{Effect of foaming stabilizer and whipping time on foam stability}

The effect of foaming stabilizer $\left(\mathrm{X}_{2}\right)$ and whipping time $\left(\mathrm{X}_{3}\right)$ on foam stability of papaya pulp at constant foaming agent $\left(\mathrm{X}_{1}\right)$ at middle level, i.e. $7.5 \%$ is shown in Fig. 2(c). The foam stability was found to be increased as the foam stabilizer and whipping time was increased up to $0.57 \%$ and $13.28 \mathrm{~min}$, respectively. For this combination of foaming stabilizer and whipping time, the foam stability of pulp was proposed to be increased up to $76.12 \%$. Beyond this combination, the foam stability was observed to be decreased. Similar results were also reported by Kandasamy et al., (2012b) during the experiment of preparation of foam mat dried papaya powder.

\section{Regression analysis and model fitting for foam stability}

The regression analysis and ANOVA results for the foam stability of papaya pulp are shown in the Table 2. The linear effect of foaming agent indicated non-significant $(p>0.05)$ positive effect on foam stability. While the linear effect of foaming stabilizer and whipping time found to be negative on foam stability. However, the linear effect of foam stabilizer on foam stability was found not significant $(p>0.05)$ and the linear effect of whipping time was found significant $(\mathrm{p}<0.05)$ on foam stability. All the quadratic effects on foam stability was found negative and significant at $0.1 \%$ level of significance.

The interaction effect between foaming agent and foaming stabilizer and the interaction between foaming agent and whipping time was found to be negative on foam stability. However, the interaction effect between foaming stabilizer and whipping time was found positive on foam stability. All the interaction effects for the foam stability were found to be non significant ( $p>0.05)$. The model as derived and giving the empirical relation between the foam stability of papaya pulp and the test variables in coded units, was obtained as under:

Foam stability $=76.32+1.59 \mathrm{X}_{1}-0.1819 \mathrm{X}_{2}$ $-1.99 \mathrm{X}_{3}-0.5338 \mathrm{X}_{1} \mathrm{X}_{2}-0.5413 \mathrm{X}_{1} \mathrm{X}_{3}+1.48$ $\mathrm{X}_{2} \mathrm{X}_{3}-4.73 \mathrm{X}_{1}^{2}-8.32 \mathrm{X}_{2}^{2}-5.78 \mathrm{X}_{3}^{2}$

Where, $X_{1}, X_{2}$ and $X_{3}$ are the coded factors of foaming agent, foaming stabilizer and whipping time, respectively.

The calculated F-value, $R^{2}$, Adj- $R^{2}$, Pred. $R^{2}$ and Adeq. Precision values for foam expansion 23.48, 0.9548, 0.9141, 0.7398, 14.04, respectively, indicating the adequacy, good fit and high significance of the model.

The small value of coefficient of variation (5.53\%) for foam expansion explained that the experimental results were precise and reliable (Table 2). 


\section{Foam density}

\section{Effect of foaming agent and foaming stabilizer on foam density}

Fig. 3(a) shows the response surface curve for the variation in the foam density of papaya as a function of foaming agent $\left(\mathrm{X}_{1}\right)$ and foaming stabilizer $\left(\mathrm{X}_{2}\right)$. It shows the interactive effect of foaming agent and foaming stabilizer on the foam density of papaya pulp, keeping the whipping time $\left(\mathrm{X}_{3}\right)$ at middle level, i.e. 15 $\min$. The decremented effect of foaming agent and foaming stabilizer up to $5.26 \%$ and $0.54 \%$, respectively was observed on foam density. The foam density at this combination was expected to be decreased up to $0.37 \mathrm{~g} / \mathrm{cc}$. Upon further rise in the foaming agent and foaming stabilizer, the foam density of pulp was found to be increased slightly.

\section{Effect of foaming agent and whipping time on foam density}

The graphical presentation of effect of foaming agent $\left(\mathrm{X}_{1}\right)$ and whipping time $\left(\mathrm{X}_{3}\right)$ on foam density of papaya pulp, keeping foaming stabilizer $\left(\mathrm{X}_{2}\right)$ at middle level, i.e. $0.6 \%$ is shown in the Fig. 3(b). The foam density was decreased with an increase in foaming agent and whipping time up to $5.46 \%$ and $13.50 \mathrm{~min}$, respectively. This interaction was expected to be effective to decrease the foam density up to $0.37 \mathrm{~g} / \mathrm{cc}$. Further increase in the foaming agent and whipping time has increased the foam density till their maximum level selected in the experiment. The bubbles formed during the foaming process were unstable at lower foaming agent concentration as the critical thickness required for the interfacial film cannot be formed at that concentration of foaming agent. This was one of the reasons for increase in the foam density. In addition to this, the collapse of bubbles and mechanical deformation during increased whipping time caused sudden increase in foam density. Similar action on foam desnity was also observed by Bag et al., (2011) in bael pulp and Falade and Okocha (2012) in plantain.

\section{Effect of foaming stabilizer and whipping time on foam density}

The effect of foaming stabilizer $\left(\mathrm{X}_{2}\right)$ and whipping time $\left(X_{3}\right)$ on foam density of papaya pulp while keeping the foaming agent $\left(\mathrm{X}_{1}\right)$ at middle level, i.e. $7.5 \%$ is shown in Fig. 3(c). The foam density was found to be decreased as the foaming stabilizer and whipping time was increased up to $0.55 \%$ and $12.92 \mathrm{~min}$, respectively. For this combination of foaming stabilizer and whipping time, the foam density of pulp was proposed to be decreased up to $0.37 \mathrm{~g} / \mathrm{cc}$. Beyond this combination, the foam density was observed to be increased.

\section{Regression analysis of foam density}

The regression analysis and ANOVA results for the foam density of papaya pulp are shown in the Table 2. All the linear effects, i.e. foaming agent, foaming stabilizer and whipping time were found to be positive on foam density. Among them, the linear effect of foaming agent $(p<0.001)$ and whipping time $(p<0.05)$ was statistically significant for foam density and the linear effect of foaming stabilizer was found non-significant ( $p>0.05$ ). The quadratic effect of all the individual parameters, i.e., foaming agent, foaming stabilizer and whipping time, was positive on foam density at $0.1 \%$ level of significance. The interaction effect between foaming agent and foaming stabilizer and interaction effect between foaming stabilizer and whipping time were found negative on foam density. While, the interaction effect between foaming agent and whipping time was found positive on foam density. All the interaction effects were found to be not significant $(\mathrm{p}>0.05)$. The 
empirical relationship was established between the foam density of papaya pulp and the test variables in coded units through regression analysis. The equation for foam density was obtained as under:

Foam density $=0.3773+0.0187 X_{1}+0.0025$ $\mathrm{X}_{2}+0.0087 \mathrm{X}_{3}-0.0075 \mathrm{X}_{1} \mathrm{X}_{2}-0.0000 \mathrm{X}_{1} \mathrm{X}_{3}$ $-0.0050 \mathrm{X}_{2} \mathrm{X}_{3}+0.0136 \mathrm{X}_{1}^{2}+0.0224 \mathrm{X}_{2}^{2}+$ $0.0224 \mathrm{X}_{3}^{2}$

Where, $X_{1}, X_{2}$ and $X_{3}$ are the coded factors of foaming agent, foaming stabilizer and whipping time, respectively.

The calculated F-value, $\mathrm{R}^{2}$, Adj- $\mathrm{R}^{2}$, Pred. $\mathrm{R}^{2}$ and Adeq. Precision values for foam expansion 19.92, 0.9472, 0.8996, 0.7165, 11.85, respectively, indicating the adequacy, good fit and high significance of the model. The small value of coefficient of variation $(3.01 \%)$ for foam expansion explained that the experimental results were precise and reliable (Table 2).

\section{Optimization and validation of process condition}

For the optimization, the limiting conditions applied to the selected constraints were (a) foaming agent: in the range, (b) foaming stabilizer: in the range, (c) whipping time: in the range, (d) foam expansion: maximum, (e) foam stability: maximum (f) foam density: minimum. Accordingly, the goals that were fixed for the process variables and response parameters to get the appropriate combination. The equal importance, i.e. three, was given to all the independent variables as well as response parameters while optimizing the process parameters. Upon the applied constraints, the optimum treatment conditions were obtained as, $6.55 \%$ foaming agent, $0.57 \%$ foaming stabilizer and $13.9 \mathrm{~min}$ whipping time. The analysis showed that at the optimized levels of foaming agent, foaming stabilizer and whipping time, it would be possible to increase the foam expansion up to $153.13 \%$ and foam stability up to $75.10 \%$ while the foam density would be decreased up to $0.37 \mathrm{~g} / \mathrm{cc}$. The experiment value analysis showed that at this combination of foaming agent, foaming stabilizer and whipping time, foaming properties of papaya pulp was foam expansion of $148.63 \%$ with a deviation of $2.93 \%$, foam stability of $74.16 \%$ with a deviation of $1.25 \%$ and foam density of 0.38 $\mathrm{g} / \mathrm{cc}$ with a deviation of $2.70 \%$. The closeness of the observed and predicted responses indicated the validity of developed models.

In conclusion this study, whey protein isolate was used as foaming agent and methyl cellulose as foaming stabilizer. Using response surface method, the optimized values were found to be $6.55 \%$ of whey protein isolate, $0.57 \%$ methyl cellulose and $13.9 \mathrm{~min}$ of whipping time to obtain maximum foam expansion and foam stability with minimum foam density for foamed papaya pulp.

\section{References}

Anderson, M. J. and Whitcomb, P. J. (ed). 2005. RSM Simplified - Optimizing Processes Using Response Surface Methods for Design of Experiments, Productivity Press, New York.

Anonymous. 2018. Horticultural Statistics at a Glance 2018, From Horticulture Statistics Division, Department of Agriculture, Cooperation and Farmers Welfare, Ministry of Agriculture and Farmers Welfare, Government of India. Available at https://agricoop.nic.in/statistics/hortic ulture accesed on 1st October 2019, pp. 181-432.

Anonymous. 2019. Department of Horticulture, Districtwise estimated 
area \& production of horticultural crops for the year 2018-19. Director of Horticulture, Agriculture, Farmar Welfare and Co-operation Department, Government of Gujarat. Available at https://doh.gujarat.gov.in/Images/direc torofhorticulture/pdf/statistics/Area-

Production-horticulture-2018-19. pdf accessed on $2^{\text {nd }}$ February, 2020.

Bag, S. K.; Srivastav, P. P. and Mishra, H. N. 2011. Optimization of process parameters for foaming of bael (Aegle marmelosL.) fruit pulp. Food and Bioprocess Technology, 4(8):14501458.

Chandak, A. J. and Chivate, M. R. 1974. Studies in foam-mat drying of coffee extract. Indian Food Packer, 28(2): $17-27$.

Durian, D. J. 1995. Foam mechanics at the bubble scale. Physical review letters, 75 : 4780-4784.

Falade, F. O.; Adeyanju, K. I. and UzoPeters, P. I. 2003. Foam mat drying of cowpea (Vignaunguiculata) using glyceryl monostearate and egg albumen as foaming agents. European Food Research and Technology, 217(6): 486-491.

Falade, K. O. and Okocha, J. O. 2012. Foammat drying of plantain and cooking banana (Musa spp.) Food and Bioprocess Technology 5(4): 11731180.

Gajanana, T. M.; Gowda, I. N. D. and Reddy, B. M. C. 2010. Exploring market potential and developing linkages-a case of underutilized fruit products in India. Agricultural Economics Research Review, 23: 437443.

Hardy, Z. and Jideani, V. A. 2017. Foam-mat drying technology: A review. Critical Reviews in Food Science and Nutrition, 57(12): 2560-2572.
Kadam, D. M.; Patil, R. T. and Kaushik, P. 2010. Foam mat drying of fruit and vegetable product. Drying of Foods, Vegetables and Fruits, 1: 111-124.

Kandasamy, P.; Varadharaju, N. and Kalemullah, S. 2012a. Foam mat drying of papaya (Carica Papaya L.) using glycerol monostearate as foaming agent. Food Science and Quality Management, 9: 17-27.

Kandasamy, P.; Varadharaju, N.; Kalemullah, S. and Moitra, R. 2012b. Preparation of papaya powder under foam mat drying technique using egg albumin as foaming agent. International Journal of Bio-resource and Stress Management, 3(3): 324333.

Khuri A. I. and Cornell, J. A. (1987) Response surface design and analysis. Marcel Dekker, Inc., New York.

Kudra, T. and Ratti, C. 2006. Foam matdrying: Energy and cost analyses. Canadian Biosystems Engineering, 48: 3.27-3.32.

Kumar, L. S. S. and Abraham, N. S. 1943. The papaya, its botany, culture and uses. Journal of the Bombay Natural History Society, 43(1):5.

Montgomery, D. C. 2001. Design and analysis of experiments, Wily, New York. pp. 416-419.

Morgan, A. I.; Graham, R. P.; L. F. Ginnette, and G. S. Williams. 1961. Recent developments in foam-mat drying. Food Technology, 15(1): 37-39.

Myres, R. H. 1976. Response Surface Methodology, Department of Statistics, Virginia Polytechnic Institute and State University, Blacksburg, Virginia, Distributed by Edwards Brothers, Inc., Ann Arbor, Michigan.

Rajkumar, P. and Kailappan, R. 2006. Optimizing the process parameters for foam mat drying of Totapuri mango 
pulp. The Madras Agricultural Journal, 93(1-6): 86-98.

Rajkumar, P.; Kailappan, R.;Viswanathan, R. and Raghavan, G.S.V. 2007. Drying characteristics of foamed alphonso mango pulp in a continuous type foam mat dryer. Journal of Food Engineering, 79: 1452-1459.

\section{How to cite this article:}

Parmar, A. R., P. R. Davara, N. U. Joshi, P. J. Rathod and Antala, D. K. 2020. Optimization of Process Parameters for Foam Mat Dried Papaya Powder. Int.J.Curr.Microbiol.App.Sci. 9(11): 669-681. doi: https://doi.org/10.20546/ijcmas.2020.911.082 